\title{
Perception of Students about the Rights and Responsibilities of Citizens: The Case of Kosovo
}

\author{
Dr. Bahtije Gerbeshi Zylfiu \\ Associate Professor, University of Prishtina, Faculty of Education \\ email: bahtie_gerbeshi@hotmail.com
}

\section{Doi:10.5901/jesr.2014.v4n2p219}

\section{Abstract}

\begin{abstract}
Even in Kosovo, as in other countries, students are agents of change. They have good ideas to change the world around them. Therefore, we must make efforts to strengthen the students' ideas of rights and responsibilities to all people. Students, who are the part of the changes, first will change themselves and later they will change the area where they live. The main purpose of this paper is to present the students' perceptions regarding the rights and responsibilities of citizens. This study will be based on the results of a survey which was carried out in lower secondary schools in Kosovo. The research was performed in rural and urban schools. In the research were involved eighth grade students. Students are selected randomly. In this study were used qualitative and quantitative methods. Questionnaires have been the main instrument of research. Besides questionnaires, were made interviews with teachers. Since students are important agents who affect social change, then the outcomes of this research are very important and these will contribute to create a clear picture regarding the beliefs and attitudes of students to the rights and responsibilities of citizens. This study will assist in the promotion of justice and equality between different groups in our society. Also, to create clear ideas of students and increase their awareness of the importance of rights and responsibilities of citizens in our democratic society an important role has some other factors. In this regard, an important contribution can also provide schools, teachers, parents, textbooks and curricula. Finally, we must mention that Kosovo's schools are being a serious effort to educate young people about the rights and responsibilities of different groups in society. Fostering and developing civic understandings, skills, values, and participation have always been important goals for the schools. Schools reach almost all children and young people.
\end{abstract}

Keywords: Students; Citizens; Rights; Responsibilities; Schools.

\section{Introduction}

Kosovo is undergoing deep transformation in the education system. To assist transformation in the system of education should be solved the goals to focus on. Taylor and Fratto (2012) have concluded that the goals you choose to focus on should help you transform your learning environment for your students and restore, if necessary your passion for teaching. You owe in to your students and to yourself (p. 32). One of the reasons to transform the education system is because demands of the new millennium for the purpose of preparation young people are different from those who lived in the past.

According to Taylor and Fratto (2012) "We also use the shift to $21^{\text {st }}$ century learning environments as the example for change taking place in your classroom and school (p.30). We are living in a unique time in education, and we need to progress from what we know and are comfortable doing to leading $21^{\text {st }}$ century skills in our classrooms. You may choose to focus on creating new communication methods for yourself, your students, and their parents. Another possibility could be creating collaboration methods for students that allow them to not only work together within the class, but also branch out to the community and students across the world (p. 32)".

To fulfill all these requirements which help transformations in education, priority issue for Kosovo society is to educate young people about the rights and responsibilities. However, first of all, students should first learn what democracy is and then understand what are their rights and responsibilities and how they should participate critically and contribute in the democratic society. Christenson et al. (2001) has expressed their beliefs by saying that: "democracy is more than a way to elect government officials or demand rights and services. Learning about democracy involves more than rote memory of government structures. It requires both the development of skills and a change in consciousness that comes from practical experience and theoretical reflection. The public work approach recognizes self-interest as a powerful motive to participation. With self-interest come the controversy, differences, and need for compromise that citizens bring to the public arena (p.96)". Equality, social justice and liberty are closely related to each other. As the 
Barber (1993) says: "There will be no liberty, no equality, no social justice without democracy, and there will be no democracy without citizens and the schools that forge civic identity and democratic responsibility." There is only one road to democracy: education (America Skips School, Harper's Magazine, p. 46).

Therefore, the Kosovo education system is essential to ensure Citizens education. However, the question is: How to reach this goal? Who are the key actors that help in this regard (matter)?

How might students in the educative institutions best learn to understand and participate in this regard? What should the schools teach and what must teachers know in order to teach these rights and responsibilities in effective and responsible ways?

Through this paper an attempt is made to answer these questions and other questions, too. This will be carried out based on the outcomes of the research performed in primary schools in Kosovo. Survey has been organized within the project "The concepts of citizenship among primary school students in Kosovo".

The "The concepts of citizenship among primary school students in Kosovo", has been conducted jointly by the three institutions, Kosovo Education Center (KEC), University of Zurich (Switzerland) on Teachers' Education and the Faculty of Education of the University of Pristina.

The paper "Perception of students rights and responsibilities of citizens: the case of Kosovo ", aims to inform everyone regarding the attitudes and beliefs of students about their rights and responsibilities. This paper is important due to its outcomes. The research results indicate a serious effort to institutions and other persons who are responsible for the education of young citizens in Kosovo on the spirit of democratic principles. In future, also the results of this research will serve teachers to focus seriously on raising students ' awareness of the importance of education on their rights and responsibilities. The paper will also serve young researchers to make comparative studies in the field of civic education in general, as well as provide them education about their own rights and responsibilities in particular.

\section{Education on Rights and Responsibilities}

Education for civil rights and responsibilities helps the overall development of a democratic society. Therefore, it is in the interest of the individual and society that these rights and responsibilities be understood and well developed. Otherwise, where no social restraint exists, anarchy reigns. That is not freedom; it is a jungle without rules or ethics. Civilization demands both freedom and responsibilities.

As in many countries in the world as well as here in Kosovo, human rights are guaranteed by law. According to the Constitution of Kosovo, Article 21 [General Principles] rights and fundamental freedoms are indivisible, inalienable and inviolable and are the basis of the legal order of the Republic of Kosovo. Republic of Kosovo protects and guarantees the rights and freedoms stipulated in this Constitution. Everyone has the obligation to respect human rights and fundamental freedoms of others. Article 7 [values] constitutional order of the Republic of Kosovo is based on the principles of freedom, peace, democracy, equality, respect for human rights and fundamental freedoms and the rule of law, non-discrimination, property rights, environmental protection, social justice, pluralism, separation of state powers and the trade economy.

Besides the Constitution of Kosovo, in the recent years in Kosovo, in this regard, substantial assistance provided documents derived from responsible institutions of Kosovo education, i.e. Curriculum Framework of Kosovo, administrative guidelines, education development strategic plan, etc. Through all these documents and many others continuous efforts are being made to raise awareness about the role and importance of education on rights and responsibilities of citizens. According to these documents, the schools, the teachers but also other relevant factors, whether parents or civil society in general, must be engaged in educating young people in the democratic spirit. Also, content of civic education gives a specific contribution to educating young people about the rights and responsibilities. This course provides ample knowledge and informs us (notify) with the essential requirements of effective citizenship.

To meet the challenges facing the new education system, the roles of teachers in Kosovo are being reconnected. If lawyers of civic education see the application of its principles as a hopeful way to reach all schoolchildren, then teachers have one obligation to investigate what civic education has to offer them. Teachers should be supported and be prepared to make changes that are necessary to understand the role of civic education and its aim to understand the needs of developing competencies that represent the essence of fulfilling the roles of educators in general.

Becoming a reflective educator and realizing where we started and where we have come, why we learn to develop and improve our profession and trying to improve quality and efficiency in preparing our young people, teachers are the main key to making the necessary transformations in education. First of all, students need to learn what democracy is and then understand what are their rights and responsibilities and how they should participate critically and to contribute in the democratic society. 
According to Christenson et al. (2001) "democracy is more than a way to elect government officials or demand rights and services. Learning about democracy involves more than rote memory of government structures. It requires both the development of skills and a change in consciousness that comes from practical experience and theoretical reflection. The public work approach recognizes self-interest as a powerful motive to participation. With self-interest come the controversy, differences, and need for compromise that citizens bring to the public arena (p.96)".

Education and training of young people to respect the human rights besides being closely linked to the education system, it also depends on the level of a society's culture. Education is not a private matter. There is always a cultural context. There can be no definition and development of self apart from culture. The broader the context of enculturation is, the better the prospects for education and for a self capability to participate comprehensively in the human conversations. So, the dilemma for education as the hope for sustaining a balance between individuality and civics (devotion to civic interest and causes) is its very nature.

We can finally say that a society can be free only when the rights of its citizens are respected. Rights always go together with responsibilities. "Strengthening rights is dependent on strengthening the connections, conceptually and behaviorally, between rights and responsibilities." (Dyck A. J. 2005). When we have rights, we will also have responsibilities. Responsibilities are the things we should do because they are right or necessary.

\section{Research Methods}

For the realization of the research are used mixed, qualitative and quantitative methods. This combination of methods was made taking into account the objectives of the research. Also for the realization of this study we have used the appropriate literature.

The instruments used in this research were questionnaires for students and questionnaires for teachers. The questionnaire was developed in 2009 when its pilot was conducted in four elementary schools of Pristina city. This is done in the first phase of research. Besides eighth grade students, at this phase of the research are included some teachers of civic education. Teachers who answered the questionnaires have been selected at random, regardless of age and gender. In the second phase a field research was done. The research included 1700 students belonging to different nationalities (Albanian, Serbian, Roma, Ashkali, Bosnian and Turkish). The study included eighth grade students from a total of 142 primary schools of Kosovo, urban areas (49.4\%) and rural (50.6\%).

The research reflects the perceptions of students regarding the concepts of citizenship. The students have given their opinions on various issues relating to the rights of ethnic groups, respect for gender equality, school, teachers, friends, etc.. After completion of the field work a data base is established. Later, for data analysis was used the SPSS program. Statistical data is also presented in graphics.

For the realization of this paper, we have singled out only some of the responses that students have shown in certain sections of the questionnaire. Questions and answers of the students which are analyzed and presented in this paper are directly related to the topic of this paper. The questionnaire includes a total of 12 sections. We are mainly focused on the detailed analysis of data arising from section: rights and responsibilities. However, besides that, some questions of other sections are analyzed: citizens and society; school curriculum; class. (See Tab. 1.)

(Tab.1) Table of sections and questions

\begin{tabular}{|c|c|c|l|}
\hline Section & Title of Section & $\begin{array}{c}\text { Nr. of } \\
\text { questions }\end{array}$ & \\
\hline & Rights and & 1 & Q (F1) Men and women should have equal opportunities to participate in government. \\
F & 2 & Q (F2) All ethnic groups should have an equal opportunity for proper education in Kosovo. \\
& responsibilities & 3 & Q (F3) Children of poor families should have an equal opportunity for proper education in Kosovo. \\
& & 10 & Q (F10) Members of all ethnic groups should be encouraged to competein elections, in order to win political posts. \\
\hline & & 1 & Q (A1) Everyone should always have the right to express his opinion freely. \\
A & Citizens and & 8 & Q (A8) All people should respect the social and political rights. \\
& society & 10 & Q (A10) All ethnic groups living in the same country must be tolerant to each other. \\
& & 17 & Q (A17) Young people must commit to participate in activities which benefit the community. \\
\hline J & School curricula & 1 & Q (J1) In school I have learned to understand people who have different opinions. \\
\hline M & Classroom & 5 & Q (M5) The teachers encourage the students to discuss issues with people who have different opinions. \\
\hline
\end{tabular}

\section{Analysis Result}

This section will reflect the data received from the students' responses to the questionnaire. These data presents 
perception of students regarding the rights and responsibilities of different groups in society and the main factors affecting the education of rights and responsibilities of citizens. From the section titled: The rights and responsibilities, we will analyze the responses from students and their perception emerges for: equality between men and women, the right to proper education for all ethnic groups living in Kosovo; the rights for education of children of poor families, as well as to encourage members of different ethnic groups to participate in elections and win the competition for political positions.

To understand the students' perception regarding equal opportunities between men and women to participate in government, students who have been surveyed in Q (F1) gave the following answers: most of the students $82.9 \%$ said "completely agree" $12.1 \%$ said "partly agree" $3.1 \%$ of them "do not agree" while only $1.0 \%$ of students said "strongly disagree". If we consider the responses of respondents in general, then we can conclude that students have a perception, belief and positive attitudes towards gender equality. However, despite these results derived from this research, gender inequalities are evident in Kosovo society. Recently, the researches done in this regard provide the indicating data that the rate and percentage of girls' enrollment at lower levels of education does not differ much from that of men. However gender differences go alongside increasing the level of education. As we go further towards the education levels, the number of male students increases and the number of female students reduces.

This data requires a serious commitment of institutions and competent persons. As a society we need to focus on public awareness regarding the importance of educating girls in order to achieve gender equality. On the contrary, equal participation of men and women in government, in our opinion cannot be productive. Only women and men with authentic education can establish a government and lead a country that will ensure political equal opportunities for women as well as men. Education for gender equality should achieve through school programs, textbooks and courses that create a broad cultural background, so that young people will have sufficient knowledge about the role and importance of gender equality. This means that schools, curriculum and teachers are important factors that contribute in eliminating gender differences. (See Chart No.)

Chart No.1. Data from Q (F1)

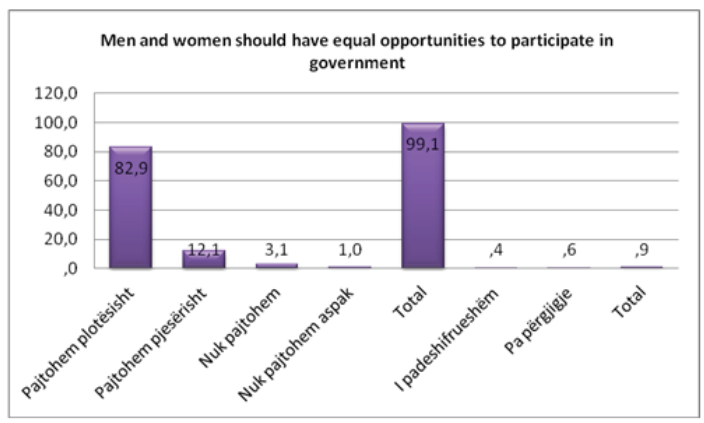

Data from Q (F2) is: $81.2 \%$ of students said "totally agree" $14.8 \%$ said "partly agree" $2.4 \%$ of them "do not agree" while only $0.5 \%$ of the students have said "strongly disagree ". From analysis' results are observed perceptions of students for the opportunities that should be provided to all ethnic groups living in Kosovo for proper education. The availability of young students for support to ethnic groups is clearly noticed. In this regard, it is certain that the subject of civic education has played a significant role, which is taught in schools of different levels in Kosovo. According to Musai, B (2003) "Preparation of a democratic society citizens who think critically and are able to solve problems, from those of closest environment, in local, national and global levels, are aware of today's education process "(p. 9). The process of education and the construction of a European society require that national citizenship be supplemented by European citizenship so that students feel themselves as European and world citizens. Due to this reason, our citizens must respect the rights of all ethnic groups living on its territory. (See Chart No. 2.). 
Chart No. 2. Data from Q (F2)

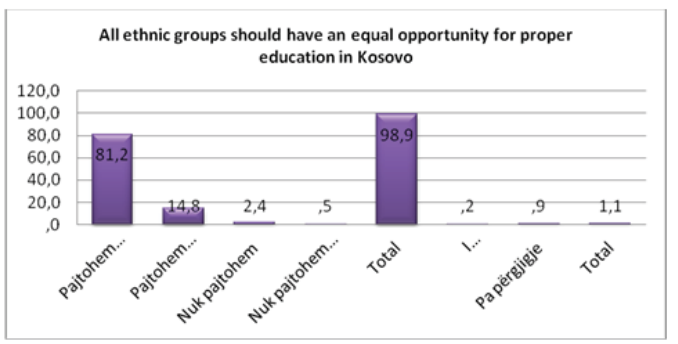

Results emerged from Q (F3) are as follows: $88.1 \%$ of respondents said they "completely agree", $8.2 \%$ said "partly agree", $2.2 \%$ of them "do not agree", while only $0.4 \%$ of students said "strongly disagree". If we consider these results as positive from the field, then we can conclude that the young people of Kosovo are being prepared to be direct participants in the development of true democracy in the country where they belong. A fact should be noted, if a democratic state does not care for its' poor people, then it is not such a state. Where there is no care for the poor, it can be talked about aristocracy, but in no way could be talked about democracy. Democracy means that the state cares for the poor precisely. Children of poor families should be provided with proper education because it is one of the basic conditions of democracy. (See Chart No. 3.)

Chart No. 3. Data from Q (F3)

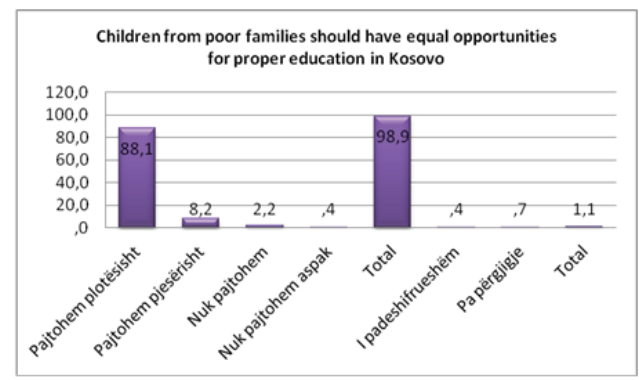

Data from Q (F10) are as follows: $38.9 \%$ of respondents said "completely agree", $41.6 \%$ of them "partly agree", while $13.1 \%$ of them "disagree" about the idea that members of ethnic groups should be encouraged, to compete in elections, to win political positions, whereas only $3.8 \%$ of respondents said they "strongly disagree".

As Chapin J. R. (2006) says, many organizations and various institutions should improve civic education in the schools. Among their concerns is the number of young people who do not vote and who are disengaged from civic and political institutions. In addition, some young people are not informed or do not understand how to participate fully in their democratic society. On the positive side, more young people believe in helping others through community services and volunteering (p. 213). (See Chart No. 4)

Chart No. 4. Data from Q (F10)

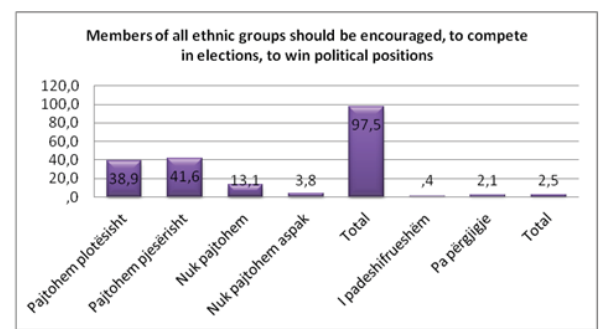


The results from the $\mathrm{Q}(\mathrm{A} 1)$ are also very interesting. The majority of respondents are aware that in a democratic society everyone should have the right to express his opinion freely. By the respondents $82.6 \%$ said they "completely agree", while $14.6 \%$ of them stated "I agree", $1.1 \%$ of them said "disagree", whereas only $0.4 \%$ of students said "strongly disagree". (See Chart No. 5)

Chart No. 5. Data from Q (A1)

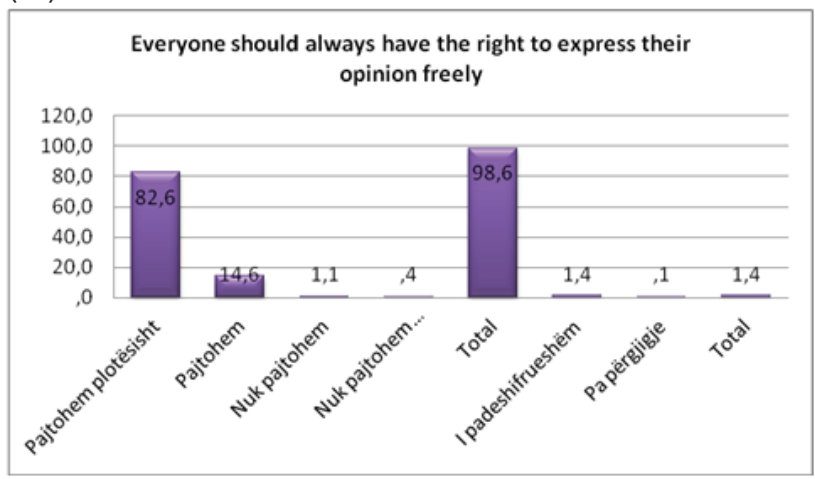

The results from the Q (A8) are as follows: $66.1 \%$ of respondents said "totally agree", while $28.6 \%$ of them stated "agree", $2.1 \%$ of them said "disagree", while only $1.1 \%$ of students said "strongly disagree". (See Chart No. 6). According to Nelson et al. (2004) Dewey recognized social conditions constantly change and schools always have to adjust to new demands placed on communities. When social problems overwhelm community resources, schools are expected to lend strength and assistance (p.468).

Chart No. 6. Data from Q (A8)

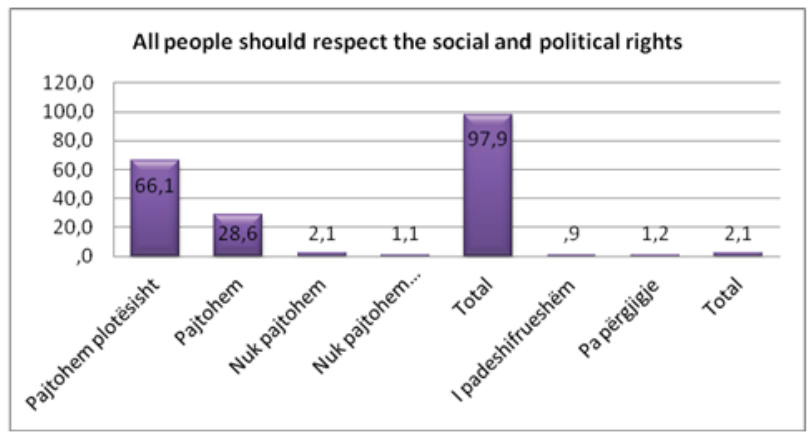

The results arising Q (A10) are as follows: $62.5 \%$ of respondents said "strongly agree", while $29.2 \%$ of them stated "agree", $4.1 \%$ of them said "disagree", while only $1.5 \%$ of the students said "strongly disagree".

Tolerance should be taught in the classroom. The classroom environment must celebrate tolerance, diversity, honor human rights, teach multiple perspectives, develop interconnectedness and interdependence, practice coresponsibility, and experience the global society. According to Brown, S. and Kysilka, M. (2002) as the world is brought into the classroom, the students must go out into the world. All ethnic groups living in a same country and in other countries in the world must be tolerant of each other if they want live together. Teachers have a responsibility to help their students prepare for the world in as many ways as possible. Part of this responsibility is to help students be actors rather than spectators in their world. Projects that involve change in local conditions, for instance, are ways to give students voices outside the classroom (p. 20). (See Chart No.7) 
Chart No. 7. Data from Q (A10)

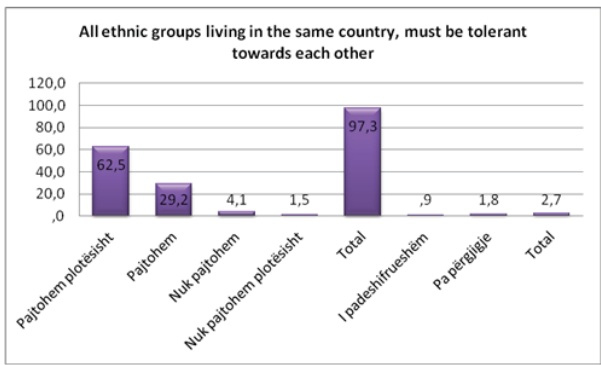

The values of the outcomes of Q (A17) are as follows: $58.8 \%$ of respondents said "strongly agree", while $31.0 \%$ of them stated "agree", $5.7 \%$ of them said "disagree", while only $1.5 \%$ of students said "strongly disagree". A good schools and curricula can contribute to producing good citizens. We should believe in the vital importance of schools and curricula instruction, both to prepare students to become responsible, thoughtful, participating citizens and to provide students with the basic skills that they need to function in our society. (See Chart No. 8)

Chart No. 8. Data from Q (A17)

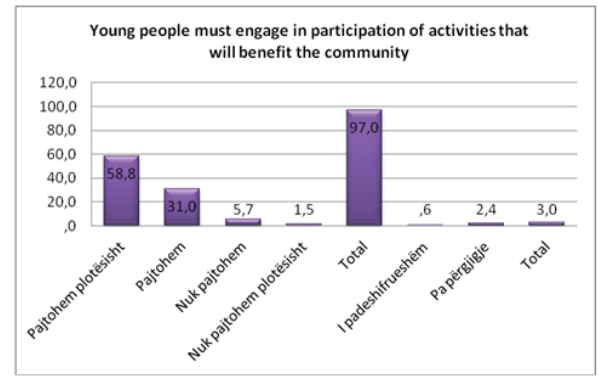

Results arising from Q (J1) are as follows: $76.1 \%$ of respondents said "strongly agree", while $19.0 \%$ of them said "partly agree", $3.2 \%$ of them said "disagree", while only $0.8 \%$ of the students said "strongly disagree". These results have shown us that the schools have learned their students to understand people who have different opinions. The idea of connecting school learning with involvement in the wider community in not new. Increasingly, teachers have come to appreciate the inherent value of student involvement in the wider community as a planned part of the larger social studies curriculum. In recent years, national, state, and local efforts to involve students in various service activities in schools and communities and related community agencies have been founded by federal and state monies (Allen and Stevens (1998, p. 91). (See Chart No. 9)

Chart No. 9. Data from Q (J1)

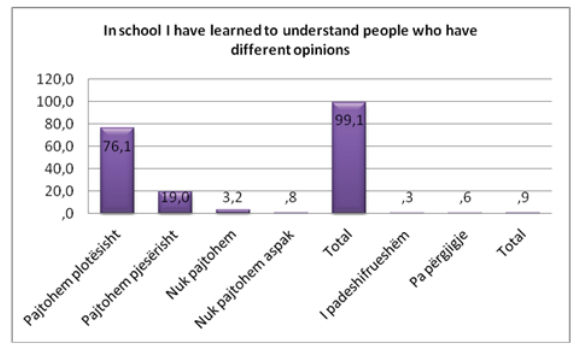

Results arising from Q (M5) are as follows: $15.1 \%$ of respondents said "never", while $20.9 \%$ of them said "rarely", $34.9 \%$ of them said "sometimes", while $27.4 \%$ of students said "often". These results have shown us that students should be encouraged more by teachers to discuss with people who have different opinions. Teachers need to encourage students 
to discuss relevant issues with people and they should ask them to reflect on those discussions.

According to Banks, J. A. (1994 b). "Teachers help their students to become "social critics who can make reflective decisions and implement their decisions in effective personal, social, political and economic action" (p. 152). Also, Brown and Kysilka (2002) believe that: "As informed citizens of the classroom, school, local community, or world, students then work for personal and societal change. Students are thus empowered to make curriculum decisions, to work out of the curriculum, and to go beyond it. The curriculum becomes the process, progress, and product of making a better world for all. (p. 117). (See Chart No. 10)

Chart No. 10. Data from Q (M5)

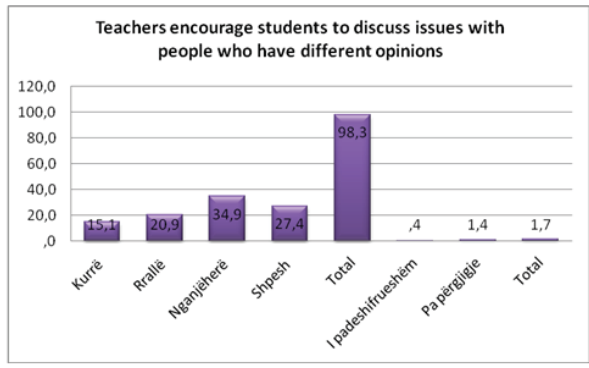

\section{Conclusion}

Kosovar society aims to be a democratic society. To achieve this goal it requires civic education of young people. Only a proper education, will directly impact on democratic civic education of students in our country. By education, people should be helped towards development to the extent where they realize that human rights are important and should be respected and protected by law. Also, citizens of Kosovo, whose purpose is the development of a democratic society should recognize and respect the rights and responsibilities of different social groups.

This research done in the field and analysis of various data derived from this research are evidence indicating that our schools have already acquired a good experience in this regard. This fact raised some hope about student's civic education in Kosovo. In other hand, the good thing is that teachers and students posses enough books which contain human rights knowledge and activities, where a special, long-term and professional contribution has been given by local bodies as well as international ones. Students through civic education must learn to integrate principles for civics in their daily lives. They must learn to be tolerant ant to change the way by which they should evaluate the various social problems.

In the end we can say that we hope that this paper will help teachers to find ways of teaching powerful civic education that teachers and their students will find enjoyable, rewarding, and meaningful. Civic education can be taught creatively and thoughtfully. As a result of teachers efforts, students may find that civic education is their favorite subject. More important, through their civic education instruction, the students will acquire the necessary knowledge, skills, and values to participate as active citizens in their society and the global community.

\section{References}

Allen, M. G. Stevens, R. L. (1998). Middle grades social studies: teaching and learning for active and responsible citizenship (2nd ed). USA: Pearson Education.

Banks, J. A. (1994 b). Multiethnic education: Theory and practice, Boston, Allyn and Bacon.

Brown, S. C. \& Kysilka, M. L. (2002). Applying Multicultural and Global Concepts in the Classroom and Beyond. Boston.

Chapin J. R. (2006). Elementary Social Studies: A practical guide (6 $6^{\text {th }}$ ed.). USA: Pearson Education.

Christenson, M. et al. (2001), Teaching together: School/University Collaboration to Improve Social Studies Education, USA, National Council for the Social Studies

Dyck, Arthur J. (2005). Rethinking Rights and Responsibilities: The Moral Bonds of Community: Georgetown University Press

Musai, B. (2003). Metodologji e mësimdhënies. Tiranë.

Oakes, J. \& Lipton, M. (2003). Teaching to change the world ( $2^{\text {nd }}$ ed). New York

Taylor, L. M., and Fratto, J. M. (2012). Transforming Learning through $21^{\text {st }}$ Century Skills: The Who Took My Chalk? Model for Engaging You and Your Students. Boston

Zmunda, A. Kuklis, R. \& Kline, E. (2004). Transforming schools: creating a culture of continuous improvement. Virginia, USA. 